\title{
Characterization of Subtilosin Gene In Wild Type Bacillus Spp. And Possible Physiological Role
}

Muaaz Mutaz Alajlani ( $\square$ muaaz01@hotmail.com )

University of Hal-le-Wittenberg

\section{Research Article}

Keywords: Subtilosin, Sbo, ribosomal peptide, Bacillus, isolation, purification.

Posted Date: January 7th, 2022

DOI: https://doi.org/10.21203/rs.3.rs-1214720/v1

License: (9) This work is licensed under a Creative Commons Attribution 4.0 International License.

Read Full License 


\section{Abstract}

In a designed study to screen for antimicrobial exhibiting bacteria using molecular aspects, Bacillus species were considered to investigate antibiotic biosynthesis genes. 28 bacterial strains and 3 induced mutants were screened for the presence of subtilosin gene $(s b o)$ and subtilosin through PCR and Mass spectrometry respectively. Sbo gene was detected in 16 out of 28 Bacillus strains. The results from gene sequences deliberated by multiple sequence alignments revealed high-level homology to the sequences of the sbo-alb gene locus of $B$. subtilis 168 and the other limited reported strains. Hence, this report provided additional strains to support the idea of subtilosin gene predominance amongst Bacillus strains isolated from environment and to find different species containing homologous genes, furthermore the utilization of its conserved region as a means of identifying Bacillus spp. that produce subtilosin. This is the first report to confirm the detection of subtilosin production from B. amyloliquefaciens.

\section{Introduction}

The soil bacterium Bacillus subtilis represents bacteria that produce a series of peptide antibiotics. They are members of both classes: the ribosomally synthesized e.g. subtilin (Gross et al., 1973; Banerjee and Hansen, 1988), Ericin (Stein et al., 2002) and sublancin (Palk et al., 1998) and the nonribosomally synthesized such as the lipopeptides surfactin (Arima et al., 1968; Leenders et al., 1999), mycosubtilin (Peypoux et al., 1976; Duitman et al., 1999), and fengycin (Umezawa et al., 1986; Vanittanakom et al., 1986; Steller et al., 1999), Bacilysocin (Tamehiro et al., 2002) and 3,3'-Neotrehalosadiamine (Inaoka et al., 2004). Subtilosin A is one of many antibiotics produced by Bacillus strains (Babasaki et al., 1985; Zheng et al., 1999; Stein et al., 2004) its importance and role in Bacillus group is little understood. Subtilosin is a macrocyclic structure (Fig. 1C) with three inter-residual linkages (Marx et al., 2001) that have been elucidated as thioether bonds between cysteine sulphurs and amino acid alpha-carbons (Kawulka et al., 2004). An acidic isoelectric point differentiates subtilosin from the basic lantibiotics (Jack and Jung, 2000; Sahl and Bierbaum, 1998). In subtilosin posttranslational linkage of a thiol to the R-carbon of an amino acid residue is unprecedented in ribosomally synthesized peptides or proteins, and very rare in secondary metabolites (Kawulka et al., 2004). The mature product is formed by loss of an unusually short seven amino acid leader peptide, cyclization of the $\mathrm{N}$ and $\mathrm{C}$ termini, and further modification of Cys, Thr, and Phe residues (Zheng et al., 1999). The mature subtilosin peptide is highly resistant to enzymatic proteolysis and is stable to moderate heat and acid treatment. It acts against a variety of Grampositive bacteria, including Listeria (Zheng et al., 1999). The production of mature subtilosin is based on the expression of the $s b o-a l b$ gene cluster encompassing the subtilosin structural gene $s b o$ and genes involved in posttranslational modification and processing of presubtilosin and in immunity (Zang et al., 1999; Zang et al., 2000). Expression of the sbo-alb genes occurs under stress conditions (Nakano et al., 2000).16S rRNA gene was used for rapid identification of the Bacillus genus was undertaken by Goto et al. (2000) and Fox et al. (1992). At this time, the validity of using a hypervariable region (nucleotides 70 to 344) of the gene was proven adequate to discriminate between all the species except between $B$. cereus and $B$. anthracis and between $B$. mojavensis and $B$. atrophaeus. The high 16S rRNA gene sequence 
similarities between some strains within this genus can even share phenotypic properties, however, they have been classified as different species based on DNA association values hence, demonstrated the need for a polyphasic approach to the systematics of this genus (Blackwood et al., 2004). This was observed between $B$. subtilis subsp. subtilis and $B$. subtilis subsp. spizizenii, which share phenotypic profiles but have segregated based on DNA reassociation values of 58 to $69 \%$, in addition to minor polymorphisms in the 16S rRNA gene between the type strains (Nakamura et al., 1999). Further, B. mojavensis and $B$. subtilis subsp. spizizenii have only a 1-bp difference in the 16S rRNA gene and can only be distinguished from each other by sexual isolation, divergence in DNA sequences of the rpoB and gyrA genes, and fatty acid composition (Nakamura et al., 1999). Recently an article was published (Stein et al., 2004) prepostulate the coding gene subtilosin gene $(s b o)$ to develop evolutionary divergence in $B$. subtilis subspecies too. This report is to describe subtilosin production by 16 wild-type $B$. subtilis strains and $B$. amyloliquefaciens. The sbo genes of these organisms were sequenced in order to analyze the genetic variation between $B$. subtilis wild-type strains. The PCR screening was correlated to production of subtilosin A.

\section{Materials And Methods}

\section{Strains and Media}

The following 32 different bacterial strains were tested for their sensitivity to the antibiotic using the agarwell diffusion assay: Bacillus subtilis 168, Bacillus subtilis ATCC, from Bacillus Genetic Stock Center (BGSC) and Bacillus cereus (Lab. collection) and 28 environmental isolates (table 1). Bacillus fusiformis was routinely used for sensitivity test. All the strains were regularly maintained on nutrient agar (Gerhardt et al., 1994), however, for antibiotic production Landy medium (Landy et al., 1948) was used.

\section{Bacterial identification:}

Identification of the isolated strains was carried on by sequence homology of $16 \mathrm{~S}$ rDNA accompanied by morphological and biochemical characterization. Identification to the species level was defined as a $16 \mathrm{~S}$ rDNA sequence similarity of $\geq 99 \%$ with that of the prototype strain sequence in GenBank; identification at the genus level was defined as a $16 \mathrm{~S}$ rDNA sequence similarity of $\geq 97 \%$ with that of the prototype strain sequence in GenBank. (July, 2006). The biochemical profile of test isolates was determined with the API 50 CHB strips following the manufacturer's instructions (bioMerieux, France). This test allows bacterial strains to be classified according to their ability to ferment 49 different carbohydrates. The results were analyzed with the APILAB Plus software (bioMerieux, France).

\section{Antibiotic assay:}

Samples of culture supernatant containing the antibiotic checked for activity using an agar- well diffusion assay (Tagg and McGiven, 1971). Fifty $\mu \mathrm{L}$ of Bacillus fusiformis liquid culture of $0.3 \mathrm{OD}_{600}$ was spread onto the surface of Petri dish containing L-agar. $50 \mu \mathrm{L}$ antibiotic sample was transferred into the well made in media plates using a sterile cork borer. The sample was allowed to diffuse into the agar and 
the plate was inverted and incubated at $37^{\circ} \mathrm{C}$ until a lawn of the indicator bacteria appeared on the plate (approximately 10-16 h).

\section{DNA isolation, extraction and PCR}

Genomic DNA extracted from overnight-inoculated bacterial culture in N-broth at $37^{\circ} \mathrm{C}$ with $120 \mathrm{rpm}$. The extraction carried out using gene extraction kit (Biorad). PCR amplification of $~ 1375$-bp consisted of sbo and flanking region was performed successfully with TS13C (GAATTGACACTATCTAGAGAAATGCCG) and TS14 (ATCCGGTGGTGCGGAATTCGATGA) (Stein et al., 2004). While primers $27 f$ (GAATTGACACTATCTAGAGAAATGCCG) and 1522r (ATCCGGTGGTGCGGAATTCGATGA) (Johnson., 1994) were used to amplify the $16 S$ rRNA gene. Both sets of primers purchased from Gene Link Inc., USA. 0.5-0.1 ng of chromosomal template DNA and $0.25 \mu \mathrm{M}$ each primer were added to Master mix (Fermantas). The PCR conditions started with heating at $94^{\circ} \mathrm{C}$ for $5 \mathrm{~min}$ and passed through 30 cycles as follows: denaturation for $30 \mathrm{~s}$ at $94^{\circ} \mathrm{C}$ primer annealation for $30 \mathrm{~s}$ at $59^{\circ} \mathrm{C}$ and extension at $72^{\circ} \mathrm{C}$ for 1.2 min. The final extension was at $72^{\circ} \mathrm{C}$ for $3 \mathrm{~min}$. PCR fragments were excised from agarose gel electrophoresis followed by extraction with a QIAgen gel extraction kit (Qiagen). The isolated PCR products were sequenced by using an $A B I$ Prism dye terminator cycle sequencing ready reaction kit and an ABI PRISM 377 DNA sequencer (Applied Biosystems). Analyses of DNA sequences were performed by using Prochromas version software (Oxford Molecular, UK).

\section{Production of (-A) No activity mutants}

Mutants from strain-7 a confirmed producer of subtilosin were generated from exposed culture to UV light for different intervals. The surviving bacteria were screened for the disruptions in sbo gene through PCR and subtilosin production by MALDI-TOF-MS.

\section{TLC, SPE and RP-HPLC}

Bacterial supernatant, recovered by $15000 \mathrm{xg}$ centrifugation for $20 \mathrm{~min}$ of $36 \mathrm{hrs}$ old shaken culture were screened for the presence of subtilosin A. Supernatants were extracted with same amount ethyl acetate (Fishers, USA) and vacuum dried. Residues were dissolved in minimal amount of acidified $20 \%$ acetonitrile v/v. Further isolation was performed through SPE columns (CHROMABOND C18ec) purchased from Macherey-Nagel, Germany. First columns were preconditioned with methanol then water and samples were applied under low pressure. The columns were washed with water and four fractions were eluted by consecutive four solutions 40, 60, 80 and 100\% acetonitrile. Fractions eluted with $80 \%$ were accommodated over short lines in TLC sheets (Merck, Germany) and developed with 1:1:1 v/v/v of $\mathrm{n}$-hexane, chloroform and methanol as mobile phase. The plates were analyzed under UV-Light, however, active fractions were detected using a narrow strips of developed sheets by a bioassay method with a sensitive test organism (Al-Ajlani and Hasnain, 2006). These active fractions were scrapped from the TLC plate and extracted with eluent A $(0.1 \%$ ( $\mathrm{vol} / \mathrm{vol})$ trifluoroacetic acid and $20 \%$ (vol/vol) acetonitrile). Finally, analysis was by reversed-phase HPLC using Thermo Hypersil-Keystone ODS (particle size, $5 \mu \mathrm{m}$; column dimensions, 250 by $4.6 \mathrm{~mm}$, Thermo Hypersil, USA). A sample was applied with eluent A and eluted with segmented gradients of eluent B ( $0.1 \%$ ( $\mathrm{vol} / \mathrm{vol})$ trifluoroacetic acid and $80 \%(\mathrm{vol} / \mathrm{vol})$ 
acetonitrile) as follow $40 \%$ eluent B for 30 min and 40 to $100 \%$ eluent B for 10 min. Eluents A and B were composed in Milli-Q HPLC grad water.

\section{MALDI-TOF-mass spectrometry}

Fractions correlated with Subtilosin A from TLC and Reverse phase HPLC were analyzed using MALDITOF-MS. $2 \mu \mathrm{L}$ of sample mixed with $2 \mu \mathrm{L}$ matrix solution $(2 \mathrm{mg}$ of alpha- hydroxycinnaminic acid per $\mathrm{ml}$ in acetonitrile-methanol-water $(1: 1: 1)$ on the target plate. MALDI-TOF-MS spectra were recorded by using a 337-nm nitrogen laser for desorption and ionization. The mass spectrometer operated in the linear mode at an accelerating voltage of $18 \mathrm{kV}$ with an ion flight path that was $0.7 \mathrm{~m}$ long. The delay time was 375 ns. Matrix suppression was also used, and the mass spectra were averaged over 50 to 100 individual laser shots. The laser intensity was set just above the threshold for ion production. External calibration was performed by using the $[\mathrm{M}+\mathrm{H}]^{+}$signals of renin, adenocorticotropic hormone, insulin oxidized $\mathrm{B}$, and bovine insulin (Sigma-Aldrich Co.) the results were anticipitated as subtilosin A with $\mathrm{m} / \mathrm{z}$ of 3400.7 and 3406.6. The variance of the $\mathrm{m} / \mathrm{z}$ of $\pm 0.8 \mathrm{Da}$ was considered acceptable.

\section{Results}

\section{Identification of Bacterial strains}

Strains were identified according to their morphological and biochemical characteristics added by homology to 16S rRNA with the type strains available in NCBI and RIDOM (Harmsen et al., 2002; Turenne et al,. 2001) the results revealed the distinction between two subsp. subtilis and spizizenii as well as their association with their sources.

\section{Detection and sequencing of sbo gene}

Sbo and its flanking region were detected from the environmental strain and Type strains. B. subtilis 168 and $B$. subtilis ATCC 6633 were used as positive control representing the two classes/ subsp. subtilis (class I) and spizizenii (class II) respectively. Results are shown in (Table 1) in which majority of strain designated as $B$. subtilis were secured sbo class I. All the obtained DNA fragments were sequenced and the phylogenetic relation was established using Clustal W, EBI. (Fig. 2).

\section{Detection and isolation and of Subtilosin}

Subtilosin presence was regularly checked on TLC in reference to match the subtilosin produced by $B$. subtilis 168 further confirmation was carried on using reverse-phase HPLC (Fig. 1A) and MALDI- TOF-MS (Fig. 1B)(Table 1).

\section{Mutation analysis}

Mutants produced further selected based on inhibitory activity. Out of 200 mutant 1 strain was isolated with no detectable zone of inhibition. This (-A) strain was not able to produce subtilosin more over the 
sbo was not amplified using PCR. Hence, it was determined to be functional disruption of encoding gene (Fig. 3B).

\section{Nucleotide sequence accession number}

The nucleotide sequences reported were deposited in NCBI GenBank under accession numbers; FJ151503, FJ151504, FJ151505, FJ151506, FJ151507.

\section{Discussion}

The ribosomal peptide antibiotics are synthesized during active growth, while nonribosomal ones are synthesized after growth has ceased. The role of antibiotic production for the producing organism is still under speculation. The best-accepted theory is that nonribosomal antibiotics may play a role in competition with other microorganisms during the starvation phase or spore germination (Mendoza et al., 1993; Zuber et al., 1993 and Stephan et al., 1993). While the role of ribosomal peptides remained undefined. Not so obvious the role of such products in the active life cycle. For example the sublancin gene cluster is not essential for B. subtilis survival (Westers et al., 2003), however, it contains yet unidentified genes mediating resistance against sublancin action. Suggestions of an intrinsic mechanism of gene improvement i.e. utilizing antibiotics as first line of defense for survival rather than a second, question antibiotics as secondary metabolites. Another probability is displayed social behaviours as coordinate gene expression and group behaviour through different quorum-sensing pathways (Shapiro, 1998). It was determined that interaction of subtilosin with the lipid head group region of bilayer membranes in a concentration dependent manner induced a conformational change in the lipid headgroup and disordering in the hydrophobic region of bilayers that ultimately resulted in membrane permeabilization at high peptide concentrations (Thennarasu et al., 2005). Such adoption may lead to assume a growth control during prosperous stage. Furthermore, under anaerobic conditions an increased by 4 - to 90 -fold, anticipated that the cell accumulates inactive precursors of subtilosin, which then undergo oxygen-dependent modifications to yield an active peptide when an aerobic environment is encountered (Nakano et al., 2000). The widespread occurrence of subtilosin might reflect an important physiological role. A specific function of subtilosin as an antibiotic, killing factor (Gonzalez-Pastor et al., 2003) or as a pheromone during anaerobiosis (Ye et al., 2000) or biofilm growth of $B$. subtilis (Kearns and Losick, 2003) could be well thought-out. Never the less the gene encoding subtilosin production has demonstrated a strong biomarker for Bacillus subtilis. The B. subtilis strains have segregated into two subclades, one encompassing strain 168 and the other W23, classified strain 168 as $B$. subtilis subsp. subtilis and W23-related strains as $B$. subtilis subsp. spizizenii based on DNA reassociation studies (Nakamura et al., 1999) and sbo gene analysis (Stein et al., 2004). The W23 and 168 group strains are identical for most phenotypic characteristics. However, cell wall chemistry of the W23 strains and 168 strains were different; the cell wall of the former contained ribitol and glycerol teichoic acids and that of the latter only glycerol teichoic acid (Burger and Glaser, 1964; Chin etal., 1966; Fox et al., 1998). The sbogene of $B$. subtilis encodes the 43-aminoacid residue comprising the prepropeptide of subtilosin (Zheng et al., 2000). The nucleotide sequences of the sbo genes and flanking regions are identical in strains 
belonging to the same subspecies, and the sequences differ by three nucleotides in the two subspecies. However, the encoded Sbo prepeptides are identical in all cases (Stein et al 2004). On the other hand sboX, encoded a bacteriocin-like product, a new gene with an unknown function, in strain 168 (Zheng et al., 2000), which resides in an open reading frame overlapping the coding region of $s b o$ (Fig. 3A). Notably, the expression of $s b o X$ would result in a 22-amino-acid curtailed peptide in W23- like strains compared to the peptide produced by 168 -like strains, which makes it unlikely that SboX is produced by W23-like strains. These observations were further elaborated to support and to evaluate possible evolutionary relationships among the subtilosin producers, however, A correlation between sbo gene and subtilosin production was not established probably due influence of sboX. Previous attempts for sboX insertions were not successful as such insertions might render sboA mRNA unstable and explain the reduced subtilosin production in sboX mutant. Alignments has revealed that the sbo genes is highly conserved with those of $B$. subtilis subsp. subtilis ( 96 to $100 \%$ amino acid identity), while the remaining were less conserved (83 to $88 \%$ identity). This high and low level of conservation is unprecedented too; for example, thymidylate synthases A (thyA) in B. subtilis subsp. spizizenii ATCC 6633 and W23 and B. subtilis subsp. subtilis (168) exhibit more than $95 \%$ amino acid identity (Tam and Borriss, 1998). Even the average level of amino acid identity for the DNA gyrases ( $g y r A$ ) in seven Bacillus type strains was 95.1\% (Chun and Bae, 2000).

\section{Declarations}

\section{Acknowledgement}

We thank Prof. D. Garozzo, Italy, for MALDI-TOF-MS of prepared samples.

\section{References}

1. Al-Ajlani MM, Hasnain S. (2006) Simple and rapid method for isolation of novel antibiotic from Bacillus subtilis Mz-7. J Liq Chrom related Tech 29:637-645.

2. Babasaki, K., Takao, T., Shimonishi, Y. and Kurahashi, K. (1985) Subtilosin A, a new antibiotic peptide produced by Bacillus subtilis 168: isolation, structural analysis, and biogenesis. J Biochem (Tokyo) 98: $585-603$

3. Banerjee, S. and Hansen, J.N. (1988) Structure and expression of a gene encoding the precursor of subtilin, a small protein antibiotic. J Biol Chem 263: 9508-9514.

4. Blackwood, K.S., Turenne, C.Y., Harmsen, D. and Kabani. A. M. (2004) Reassessment of sequencebased targets for identification of Bacillus Species. J Clin Microbiol 42: 1626-1630.

5. Chun, J. and Bae, K.S. (2000) Phylogenetic analysis of Bacillus subtilisBacillus subtilis and related taxa based on partial gyrAgyrA gene sequences. Antonie Leeuwenhoek 78: 123-127.

6. Duitman, E. H., L. W. Hamoen, M. Rembold, G. Venema, H. Seitz, W. Saenger, F. Bernhard, R. Reinhardt, M. Schmidt, C. Ullrich, T. Stein, F. Leenders, and J. Vater. 1999. The mycosubtilin synthetase of 
Bacillus subtilisBacillus subtilis ATCC 6633: a multifunctional hybrid between a peptide synthetase, an amino transferase, and a fatty acid synthase. Proc Natl Acad Sci USA 96:13294-13299.

7. Harmsen, D., Rothganger, J., Frodch, M. and Alber, J. (2002) RIDOM: ribosomal differentiation of medical micro-organisms database. Nucleic Acid Res 30: 416-417.

8. Gerhardt P, Murray RGE, Wood WA, Krieg NR Methods for general and molecular bacteriology. Washington, D.C.: American Society for Microbiology. 1994

9. Gonzalez-Pastor, J. E., Hobbs, E. C. and Losick, R. (2003) Cannibalism by sporulating bacteria. Science 301: 510-513.

10. Goto, K., Omura, T. Hara, Y. and Sadaie, Y. (2000) Application of the partial 16S rDNA sequence as an index for rapid identification of species in the genus Bacillus. J Gen Appl Microbio/ 46: 1-8.

11. Gross, M., Lewis, E. and Nagarajan, M. (1973) An improved quantitative system for assessing the acute alcoholic psychoses and related states (TSA and SSA). In 'Alcohol Intoxication and Withdrawal: Experimental Studies', Advances in

12. Experimental Medicine and Biology, Gross, M. ed., vol. 35, pp. 356-376. Plenum Press, New York.

13. Fox GE, Wisotzkey JD, Jurtshuk P Jr. (1992) How close is close: $16 \mathrm{~S}$ rRNA sequence identity may not be sufficient to guarantee species identity. Int J Syst Bacterio/ 42:166-170.

14. Inaoka, T., Takahashi, K., Yada, H., Yoshida, M. and Ochi, K. (2004) RNA polymerase mutation activates the production of a dormant antibiotic 3,3ç-neotrehalosadiamine via an autoinduction mechanism in Bacillus subtilis. J Biol Chem 279: 3885-3892.

15. Jack, R. W. and Jung, G. (2000) Lantibiotics and microcins: polypeptides with unusual chemical diversity. Curr Opin Chem Biol 4: 310-317.

16. Johnson, J. L. 1994. Similarity analysis of rRNAs. In Methods for general and molecular bacteriology ed. Gerhardt, P., Murray, R. G. E., Wood, W. A and Krieg, N. R. pp. 683-700. Washington, D.C.: American Society for Microbiology. Kawulka, K.E., Sprules, T., Diaper, C.M., Whittal, R.M., McKay, R.T., Mercier, P., Zuber, P. and Vederas, J.C. (2004) Structure of Subtilosin A, a Cyclic Antimicrobial Peptide from Bacillus subtilis with Unusual Sulfur to R-Carbon Cross-Links: Formation and Reduction of R-Thio-RAmino Acid Derivatives. Biochem 43: 3385-3395.

17. Kearns, D. B. and Losick, R. (2003) Swarming motility in undomesticated Bacillus subtilisBacillus subtilis. Mol. Microbiol. 49:581-590.

18. Landy, M., Warren, G. H., Roseman, S. B. and Golio, L.G. (1948) Bacillomycin, an antibiotic from Bacillus subtilis active against pathogenic fungi. Proc Soc Exp Biol Med 67: 539-541.

19. Leenders, F., Stein, T.H., Kablitz, B., Franke, P. and Vater, J. (1999) Rapid typing of Bacillus subtilis strains by their secondary metabolites using matrix-assisted laser desorption/ ionization mass spectrometry of intact cells. Rapid Commun Mass Spectrom 13: 943-949.

20. Marx, R., Stein, T., Entian, K.-D. and Glaser, S.J. (2001) Structure of the Bacillus subtilis peptide antibiotic subtilosin A determined by $1 \mathrm{H}-\mathrm{NMR}$ and matrix assisted laser desorption/ ionization timeof-flight mass spectrometry. J Protein Chem 20: 501-506. 
21. Mendoza, D., Grau, R. and Cronan Jr, J.E. (1993). Biosynthesis and function of membrane lipids, p. 411-421. In A. L. Sonenshein, J. A. Hoch, and R. Losick (ed.), Bacillus subtilis and other grampositive bacteria. American Society for Microbiology, Washington, D.C.

22. Nakamura, L.K., Roberts, M.S. and Cohan., F.M. (1999) Relationship of Bacillus subtilis clades associated with strains 168 and W23: a proposal for Bacillus subtilis subsp. subtilis subsp. nov. and Bacillus subtilis subsp. spizizenii subsp. nov. Int J Syst Bacteriol 49: 1211-1215.

23. Paik, S.H., Chakicherla, A. and Hansen, J.N. (1998) Identification and characterization of the structural and transporter genes for, and the chemical and biological properties of, sublancin 168, a novel lantibiotic produced by Bacillus subtilis 168. J Biol Chem 273: 23134-32142.

24. Peypoux, F., Bonmatin, J.M. and Wallach, J. (1999) Recent trends in the biochemistry of surfactin. Appl Microbiol Biotechnol 51: 553-563.

25. Sahl, H. G. and Bierbaum, G. (1998). Lantibiotics: biosynthesis and biological activities of uniquely modified peptides from gram-positive bacteria. Annu Rev Microbio/ 52: 41-79.

26. Shapiro, J.A. (1998) Thinking about bacterial populations as multicellular organisms. Annu Rev Microbio/ 52: 81-104.

27. Stein, T., Borchert, S., Conrad, B., Feesche, J., Hofemeister, B., Hofemeister, J., and Entian, K.-D. (2002) Two different lantibiotic-like peptides originate from the ericin gene cluster of Bacillus subtilis A1/3. J Bacteriol 184: 1703-1711.

28. Stein, T., Düsterhus, S., Stroh, A. and Entian, K.-D. (2004) Subtilosin production by two Bacillus subtilis subspecies and variance of the sbo-alb cluster. Appl Environ Microbiol 70: 2349-2353.

29. Steller, S., D. Vollenbroich, F. Leenders, T. Stein, B. Conrad, J. Hofemeister, P. Jacques, P. Thonart, and J. Vater. 1999. Structural and functional organization of the fengycin synthetase multienzyme system from Bacillus subtilisBacillus subtilis b213 and A1/3. Chem Biol 6: 31-41.

30. Stephan A. S. and Marahiel, M.A. (2003) Learning from Nature's Drug Factories: Nonribosomal Synthesis of Macrocyclic Peptides. J Bacterio/ 185(24):7036-7043 Tam, N. H. and Borriss, R. (1998) Genes encoding thymidylate synthases $A$ and $B$ in the genus BacillusBacillus are members of two distinct families. Mol Gen Genet :427-430.

31. Tamehiro, N., Okamoto-Hosoya, Y., Okamoto, S., Ubukata, M., Hamada, M., Naganawa, H. and Ochi, K. (2002) Bacilysocin, a novel phospholipid antibiotic produced by Bacillus subtilis 168. Antimicrob Agents Chemother 46: 315-320.

32. Turenne, CY., Tschetter, L. and Wolfe, J. (2001) Necessity of quality controlled 16S rRNA gene sequence data bases: identifying nontuberculous Mycobacterium spcies. J Clin Microbio/ 39: 36373648. (Erratum 40: 2316, 2002)

33. Thennarasu, S., Lee, D.K., Poon, A., Kawulka, K.E., Vederas, J.C. and Ramamoorthy, A. (2005) Membrane permeabilization, orientation, and antimicrobial mechanism of subtilosin A. Chem Phys Lipids 137(1-2): 38-51.

34. Vanittanakom, N., Loeffler, W., Koch, U. and Jung, G. (1986) Fengycin - a novel antifungal lipopeptide antibiotic produced by Bacillus subtilis F-29-3. J Antibiot (Tokyo) 39: 888-901. 
35. Westers, H., Dorenbos, R., van Dijl, J.M., Kabel, J., Flanagan,T., Devine, K.M., et al. (2003) Genome engineering reveals large dispensable regions in Bacillus subtilis. MolBiol Evol 20: 2076-2090.

36. Ye, R.W., Tao, W., Bedzyk, L., Young, T., Chen, M. and Li. L. (2000) Global gene expression profiles of Bacillus subtilis grown under anaerobic conditions. J Bacterio/ 182: 4458-4465.

37. Zheng, G., Hehn, R. and Zuber, P. (2000) Mutational analysis of the sbo-albsbo-alb locus of Bacillus subtilisBacillus subtilis: identification of genes required for subtilosin production and immunity. $J$ Bacteriol 182:3266-3273.

38. Zheng, G., Yan, L.Z., Vederas, J.C. and Zuber, P. (1999) Genes of the sbo-alb locus of Bacillus subtilis are required for production of the antilisterial bacteriocin subtilosin. $J$ Bacterio/ 181:7346-7355.

39. Zuber, P., Nakano, M.M. and Marahiel, M. A. (1993) Peptide antibiotics, p. 897-916. In A. L. Sonenshein, J. A. Hoch, and R. Losick (ed.), Bacillus subtilis and other gram-positive bacteria. American Society for Microbiology, Washington, D.C.

\section{Table}

Due to technical limitations, table 1 is only available as a download in the Supplemental Files section.

\section{Figures}



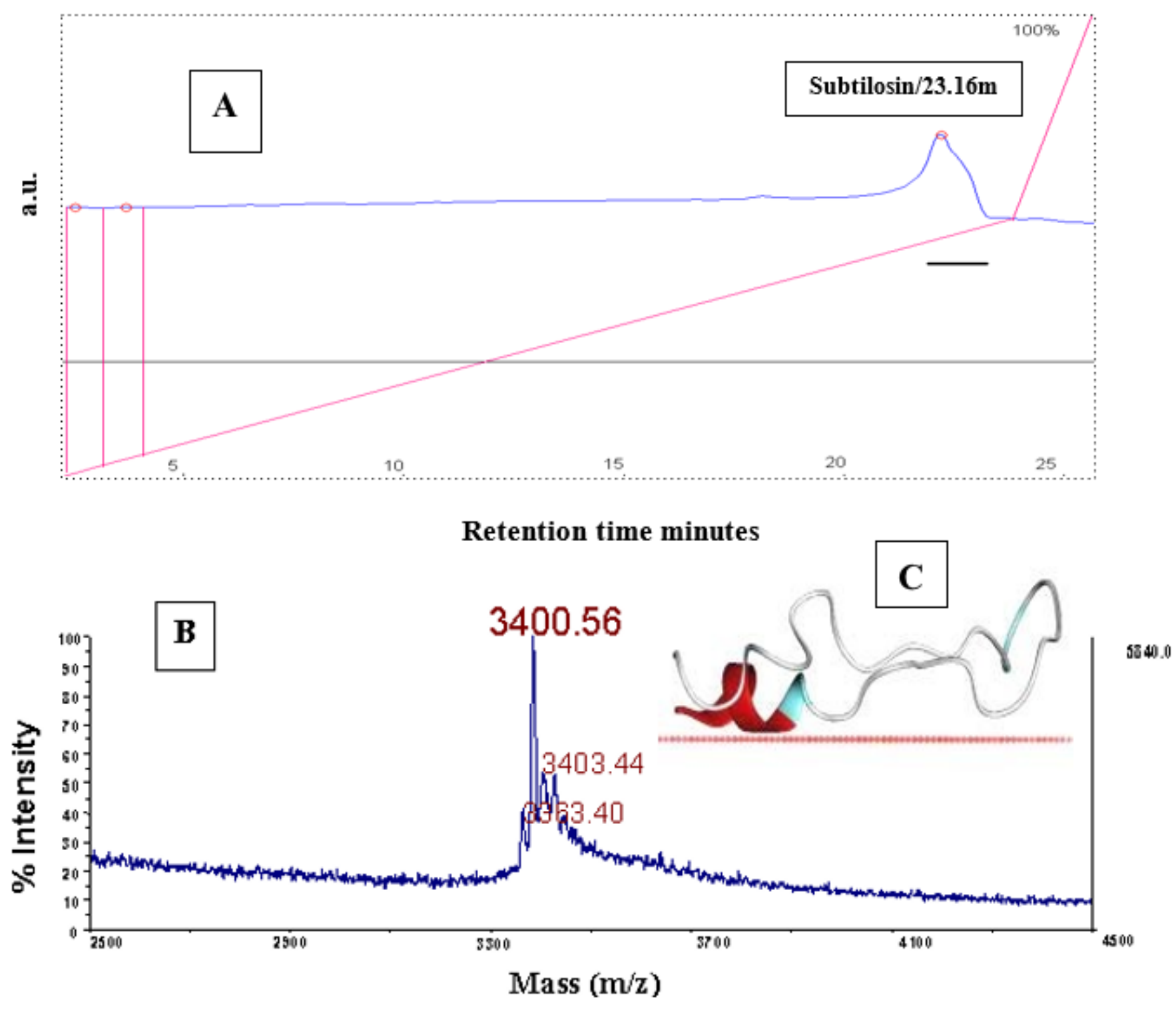

Figure 1

(A) RP-HPLC, (B) MALDI-TOF-MS, intensive signals correspond to the molecular mass of protonated subtilosin $[\mathrm{M}+\mathrm{H}]^{+}(\mathrm{C}) 3 \mathrm{D}$ structure of subtilosin. 


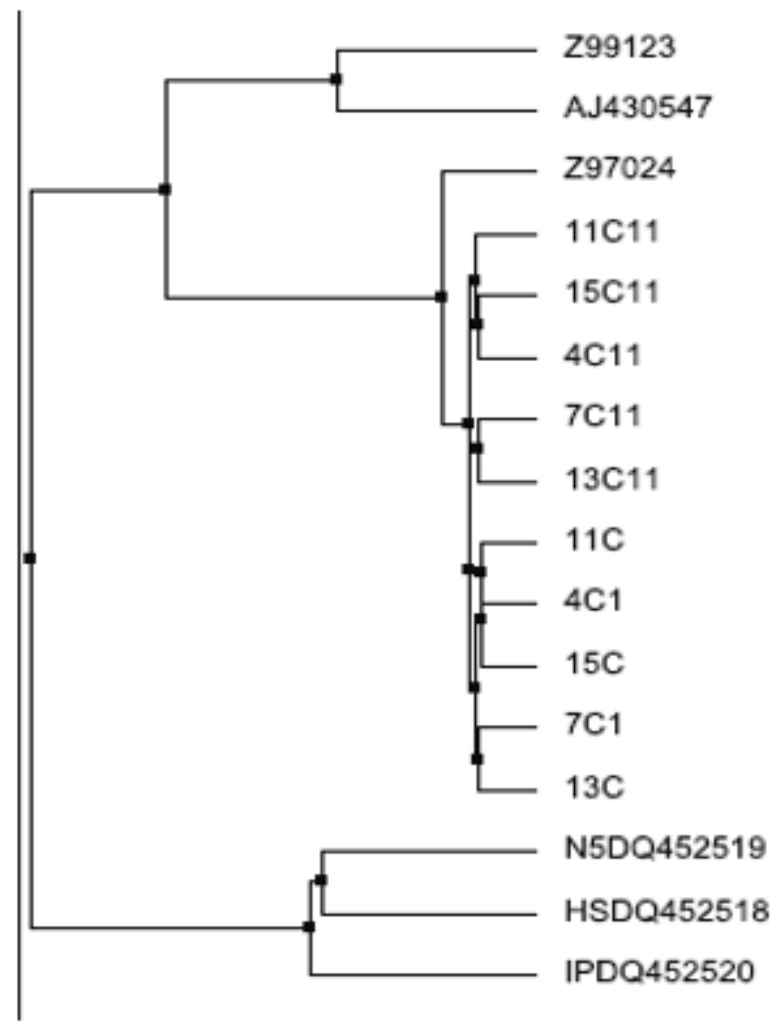

Figure 2

Phylogenetic diversity of isolated strains using multiple sequence alignments of sequences sbo and flanking region. 
A

\section{$1375 \mathrm{bp}$}

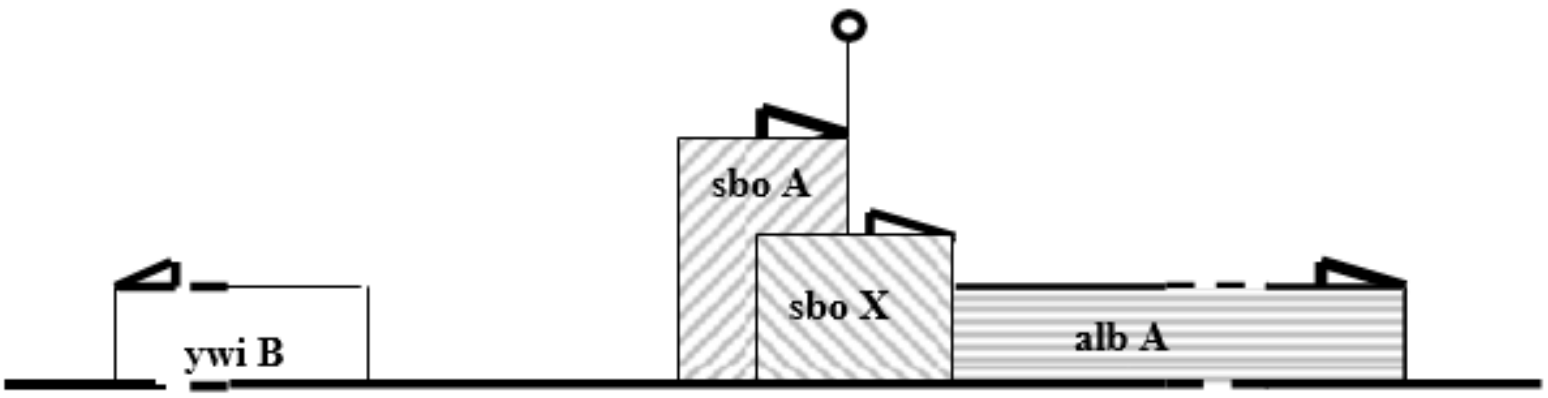

B

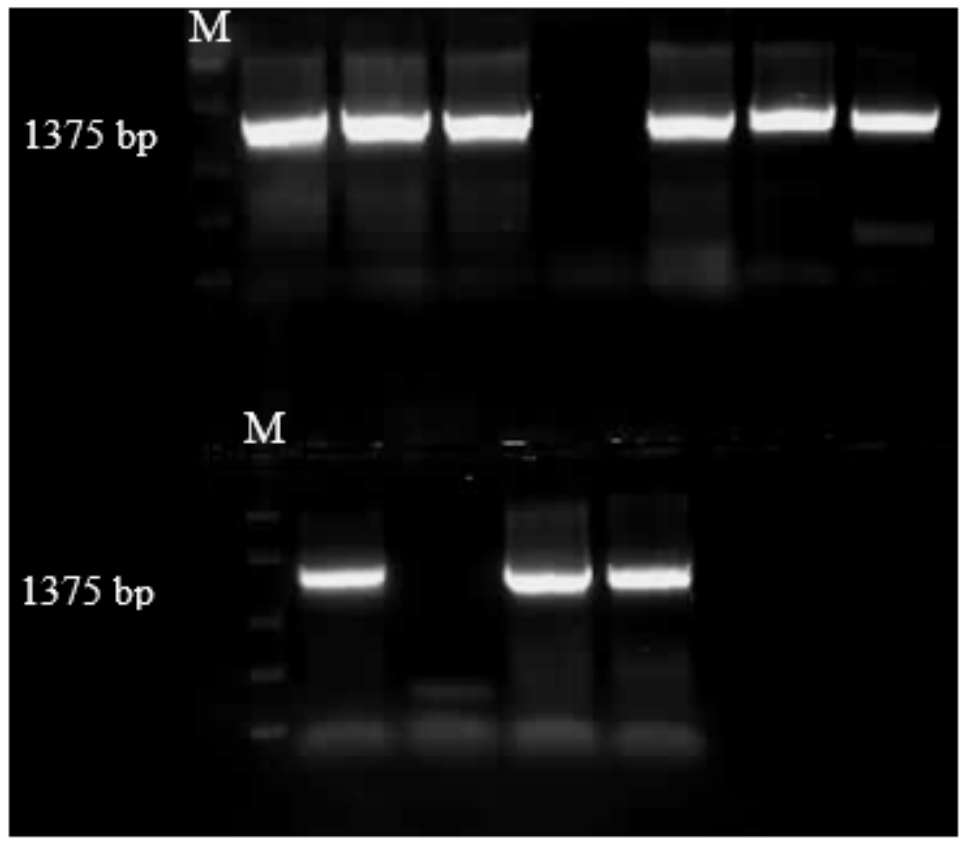

Figure 3

(A) Organization of the $s b o A X$ locus. the $s b o A$, sboX, and albA region of the sbo-alb gene cluster and flanking region. Arrowheads indicate direction of transcription; (o) is a terminator. (B) PCR amplified fragment of $1375 \mathrm{bp}$ related to sbo gene where $\mathrm{M}$ indicates marker $(5000,2000,850,400,100 \mathrm{bp})$.

\section{Supplementary Files}

This is a list of supplementary files associated with this preprint. Click to download.

- Table.docx 